\title{
How Legitimate is the Open Method of Co-ordination?*
}

\author{
MILENA BÜCHS \\ University of Southampton
}

\begin{abstract}
This article argues that the OMC's legitimacy can be improved only by strengthening parliamentary channels of input-legitimacy since output-legitimacy alone is inappropriate and cannot be achieved without input-legitimacy. In addition, concepts and practices of direct 'stakeholder' participation currently applied within the OMC are insufficient in strengthening input-legitimacy.
\end{abstract}

\section{Introduction}

In November 2007, the open method of co-ordination (OMC) celebrated its tenth anniversary. ${ }^{1}$ When it was initially established, the OMC was predominantly regarded as an innovative governance method at the European Union (EU) level facilitating bottom-up policy learning and strengthening the EU's social dimension through the regular exchange of information, deliberation, policy evaluation and 'naming and shaming' between the Member States. Academic interest in this phenomenon has been considerable and theoretical

\footnotetext{
* I would like to thank Dawid Friedrich, Traute Meyer, Jan-Henrik Meyer, the participants in the European Social Policy workshop at the ECPR Joint Sessions in Nicosia, April 2006, particularly Karen Anderson, Wolfram Lamping, Deborah Mabbett and Waltraud Schelkle, as well as the two anonymous referees for very useful comments on previous versions of this article.

${ }^{1}$ A significant component of the OMC, the European Employment Strategy, was launched at the Luxembourg summit in November 1997. 
articles, as well as empirical evaluations of various OMC aspects, are numerous (for general overviews, see Büchs, 2007; Zeitlin et al., 2005).

Recently, the interest in legitimacy issues regarding the OMC has also increased, which is evident in the writings of Benz (2007), Borrás and Conzelmann (2007), Duina and Raunio (2007), Hatzopoulos (2007), Kröger (2007), Papadopoulos (2007), Radulova (2007), Wincott (2006) and Tsakatika (2007). Early OMC literature was relatively optimistic regarding both its legitimacy and potential to increase the European Union's democratic quality (e.g. Eberlein and Kerwer, 2004; Gerstenberg and Sabel, 2002; Jacobsson and Vifell, 2002). However, a number of more sceptical assessments of the OMC's legitimacy have since been published, in particular those of Hatzopoulos (2007), Kröger (2007) and Tsakatika (2007).

This article charts the debate regarding the OMC's legitimacy and democratic quality by applying the criteria of output- and input-legitimacy. This distinction was developed by Scharpf during the 1970s (Scharpf, 1999, p. 6) and is utilized here as it is generally a useful distinction for analysing issues of legitimacy. It also had a significant impact on discussions regarding the EU's democracy deficit. However, this article employs a critical reading of this distinction and argues that output-legitimacy alone is neither appropriate nor can it be achieved without input-legitimacy. An analysis of inputlegitimacy within the OMC demonstrates that it primarily rests upon a model of stakeholder participation. As this model and practice is problematic from the perspective of representative-parliamentarian democracy, the article concludes that the OMC's legitimacy can only be strengthened by improving parliamentary channels of input-legitimacy. The conclusion briefly discusses a range of reform options.

\section{Why Worry About the OMC's Legitimacy?}

Firstly, one must establish why one should be concerned with the OMC's legitimacy and democratic quality. The OMC objectives are adopted by the Council of the European Union or the European Council whilst parliaments at the EU and national levels play a merely marginal role in the process. From a 'formalistic' or 'legalistic' perspective, one might argue that the OMC does not raise any legitimacy issues. This position emphasizes that the OMC is coherent with the EU's principle of subsidiarity, which allows the EU to adopt policies only if an issue cannot be adequately tackled at the Member State level. This perspective states that the OMC objectives and recommendations are not legally binding, and consequently, the EU does not interfere with the Member States' authority in the area of social policy (Borrás and 
Conzelmann, 2007, p. 533). According to this logic, a national policy reform informed by the OMC must be perceived as a voluntary, and therefore legitimate, act (Amitsis et al., 2003, p. 91). In addition, this position argues that important branches of the OMC, such as the European Employment Strategy and processes of economic policy co-ordination, are legitimized through Articles 99 and $125-30$ of the Treaty establishing the European Communities. ${ }^{2}$

A number of difficulties are inherent within this 'formalistic' approach, however. The OMC does not merely comprise minor or uncontroversial 'technical details', but promotes social policy approaches associated with fundamental values and interests (Borrás and Conzelmann, 2007, p. 532; Kröger, 2007, p. 579). Although numerous authors agree that the OMC is unlikely to affect national policy-making directly, it is becoming increasingly accepted that it may have long-term effects upon Member States' social policies through framing the perception and definition of problems, as well as related policy responses (e.g. Hatzopoulos, 2007; López-Santana, 2006). Whilst national parliaments still formally adopt social policies, the OMC restricts their role as agenda-setters and strengthens executives' influence upon agenda-setting and policy-design. In addition, the European Social Fund has been more closely linked to the OMC in recent years. ${ }^{3}$ Therefore, the OMC has a potential impact upon the European Social Fund's implementation and thus upon redistributive policies. Furthermore, some authors have argued that the European Court of Justice is potentially able to refer to OMC objectives in its decisions (Hatzopoulos, 2007, p. 335). These are indicators that the OMC possibly exerts an influence upon fundamental social policy decisions and hence requires legitimacy.

\section{Why Apply Output- and Input-Legitimacy?}

Any debate surrounding the democratic quality and legitimacy of certain governance instruments must clarify its evaluation criteria. This article applies those of output- and input-legitimacy, developed by Scharpf in the late 1970s (Scharpf, 1999, p. 6). These criteria are employed within this article as they identify two interrelated, but analytically distinct, criteria of democratic legitimacy which had a significant impact upon the debate regarding the EU's legitimacy. However, as this discussion will demonstrate, the distinction between output- and input-legitimacy has been applied in a problematic way

\footnotetext{
${ }^{2}$ Currently, the OMC in areas such as social inclusion, social protection and health has no treaty basis which could be criticized by the 'formalist' position. If the new reform treaty is ratified, this situation will be rectified (see the text of the Draft Reform Treaty on «http://consilium.europa.eu/»).

${ }^{3}$ See the new regulation on the European Social fund (EP/Council, 2006), preamble paragraphs 7, 13, 15, Article 4.1, 4.4 and 4.5.
} 
within the debate surrounding the EU's legitimacy, as well as, to a certain degree, that of the OMC.

According to Scharpf (1999), policies are output-legitimate when they produce outcomes serving the interests of the citizens, that is they are legitimate because they are effective ('politics for the people'). Policies are inputlegitimate when they reflect the citizens' will that is usually provided for by procedural arrangements related to majority rule ('politics by the people') (Scharpf, 1999, p. 6). Scharpf maintains that input-legitimacy requires citizens to possess a common political identity in order for input-legitimate processes to generate the required trust that policy outputs are related not merely to the aggregation of self-interested preferences but pursue a 'common good' (Scharpf, 1999, p. 7). In contrast, output-legitimacy can be generated without such common political identity, as political decisions must effectively solve problems and thereby fulfil the citizens' interests. Scharpf states that output- and input-legitimacy usually co-depend on one another at the national level; effective national policies can be legitimate only when they are based upon input-legitimate policy processes whilst input-legitimate policies need to be effective to be fully legitimate (Scharpf, 1999, p. 26).

The concepts of 'output' and 'input-legitimacy' have also been applied to discussions regarding the EU's legitimacy and democratic quality. Within this field, one influential perspective argues that the EU's legitimacy must primarily rely upon output-legitimacy since it is neither possible, necessary nor desirable to generate input-legitimacy.

Scharpf, for instance, maintains that it is impossible to promote inputlegitimacy at the EU level, for example, through a powerful role for the European Parliament in EU policy-making, EU party politics and the election of an EU government, as a common political identity among EU citizens is lacking. Scharpf thus argues that EU policies must be restricted to uncontroversial policy areas so that a political consensus fulfilling EU citizens' interests can be reached and, consequently, no input-legitimate policy-making processes are required (Scharpf, 1999, p. 22).

Authors such as Majone and Moravcsik also support the view that EU policies should rely upon output-legitimacy (Majone, 1998; Moravcsik, 2002). They argue that input-legitimate institutions within the EU are unnecessary as the EU is primarily engaged with regulatory policies without redistributive effects (Majone, 1998) and that the EU's institutional system already provides for accountable, transparent and median-voter-oriented policies (Moravcsik, 2002). Furthermore, both Majone and Moravcsik believe that input-legitimacy at the EU level is undesirable since a parliamentarization and politicization - of the EU would result in ineffective policy processes and suboptimal policy outcomes (Follesdal and Hix, 2005, p. 7). 
This approach has been applied to the OMC by authors such as Telò (2003), who argues that the OMC could be legitimized through its effectiveness. To evaluate this claim, the following section briefly examines the OMC's effectiveness to investigate whether it has the potential to generate output-legitimacy. Subsequently, the discussion will surpass questions regarding the OMC's effectiveness to scrutinize the appropriateness of assumptions that it could be legitimized solely on the basis of its outcomes. This will finally lead to an examination of the OMC's input-legitimacy.

\section{The OMC's Output-Legitimacy}

\section{How Effective is the OMC?}

To date, no clear consensus exists regarding the OMC's effectiveness. This is partly due to a lack of consistent evidence concerning the OMC's influence upon national policy-making, and partly related to disagreement surrounding the definition of the OMC's goals. Thus far, the majority of authors concede that whilst a direct influence of the OMC upon national policy-making is unlikely, it has the potential to 'frame' national policy-making indirectly and generate long-term effects on policies through cross-national learning (López-Santana, 2006; Trubek and Trubek, 2005; Zeitlin, 2005). Authors believing that the OMC's primary aim lies in facilitating the exchange of information and providing an opportunity for informal policy-learning may therefore conclude that this objective is fulfilled and the OMC consequently passes the effectiveness test.

However, if the OMC's effectiveness is evaluated against more ambitious targets, the outcome may be less positive. This is likely to be the case if the $\mathrm{OMC}$ is measured against its policy objectives and quantitative targets as well as expectations that it has the potential to strengthen the EU's social dimension and balance 'negative' and 'positive' integration (De la Porte and Pochet, 2002a, p. 11; European Council, 2000, para 15; Ferrera and Rhodes, 2000, p. 278).

With an employment rate of 64.7 per cent for the EU-25 in 2006, significant progress still has to be achieved if a target of 70 per cent is to be reached by $2010 .{ }^{4}$ The 'at-risk-of-poverty-rate' in the EU-25, reflecting the proportion of the population living on an income below 60 per cent of the median after

\footnotetext{
${ }^{4}$ At first glance, the employment rate of 57.3 per cent for women in 2006 appears close to the goal of 60 per cent, which is to be achieved by 2010 . However, the full-time equivalent rate for female employment only reached 48.5 per cent in 2006. The employment rate for older workers was 43.6 per cent in 2006, making the achievement of the goal of 50 per cent by 2010 unlikely, see Eurostat «http:// epp.eurostat.ec.europa.eu».
} 
social transfers, has stagnated at 16 per cent since the year 2000. Social inequality, measured by the ratio of the income received by the top quintile to the bottom quintile of the EU-25 population, has risen from 4.5 in 2000 to 4.9 in 2005. The Gini-coefficient, used as an indicator of income inequality within the EU-25, has also increased from 29 to 30 between 2000 and 2005. ${ }^{5}$ This statistical evidence demonstrates that the OMC fails to achieve many of its objectives, particularly those of 'combating poverty and social exclusion' (European Council, 2000, para 20). The mid-term review of the Lisbon Strategy in 2005 also conceded that the OMC's targets had not been fully achieved, urging to overcome the 'implementation deficit' by 2010 (Commission, 2005, p. 13).

It has also become clear that the OMC has not changed the relationship between 'negative' and 'positive' integration (Ferrera and Rhodes, 2000, p. 278; Scharpf, 1999, p. 45) as it did not affect the interpretation of how social policy competencies are distributed between the EU and the Member States. The EU's social policy competencies remain constrained through strict application of the subsidiarity principle. In addition, the $\mathrm{OMC}$ is embedded within a framework of legally binding 'negative integration' policies as well as the stability and growth pact which, although often criticized for being overly soft and ineffective, continues to play a more significant role within national policy debates and policy-making than the social policy OMC (De la Porte and Pochet, 2002b, p. 51). The negative votes within the Dutch and French referendums on the EU's Constitutional Treaty also demonstrated that some EU citizens tend to perceive the EU as a propellant for market liberalization and potential threat to national social standards (Kenner, 2005, p. 542). This evidence indicates that the OMC has not sufficiently contributed to strengthening the social dimension of the European Union. It is therefore questionable whether the OMC possesses the ability to generate output-legitimacy, as it lacks the required conditions.

\section{Legitimizing the OMC Through its Effectiveness?}

On a more fundamental level, one must discuss whether it would be appropriate to legitimize the $\mathrm{OMC}$ on the basis of its effectiveness. This section considers significant theoretical concerns in relation to the perspective that EU policies, and the OMC more specifically, can be predominantly legitimized through outcomes. The latter position relies upon several preconditions, including the existence of consensual policy solutions (Scharpf, 1999, p. 22) rendering political debate and contestation unnecessary. If consensus

\footnotetext{
${ }^{5}$ All data are sourced from the latest Eurostat figures, «http://epp.eurostat.ec.europa.eu». 
exists prior to public discussion, policies can be defined by 'agents' such as the European Commission or expert committees. A second precondition for the legitimacy of delegating policy-making to non-democratic institutions is that policy outcomes must have pareto-optimal effects, meaning that they must benefit at least one person without disadvantaging any other individual (Lord and Beetham, 2001). In other words, policies based upon outputlegitimacy must not have redistributive effects. If one scrutinizes the OMC with regards to these two preconditions, it appears that both are far from being fulfilled.

As previously mentioned, the OMC objectives, guidelines and recommendations rely upon fundamental values and decisions regarding the direction that European social policy should take (Borrás and Conzelmann, 2007). The OMC objectives promote an agenda of market-enhancing financial sustainability and welfare-to-work policies (Ashiagbor, 2005; Büchs, 2007). It cannot be assumed that this policy approach is uncontroversial amongst EU citizens and it is therefore not legitimate if decisions regarding these programmatic orientations are adopted in policy processes decoupled from open parliamentary debate.

The position assuming that experts or politicians in non-democratic institutions are able to define social problems and corresponding policy solutions fulfilling citizens' long-term interests also disregards an important function of democratic policy-making processes. For example, authors such as Habermas (2001 [1998]) and Eriksen and Fossum (2000) argue that citizens' interests do not exist independently of public political discussion and cannot be objectively identified by experts or political elites. They conversely assume that citizens' interests are formed only through public political deliberation, which therefore emerges as a crucial element of any democratic policymaking process. This appears to be an extremely valid argument, demonstrating the requirement for input-legitimacy in order to identify citizens' interests. Consequently, output-legitimacy alone is not only insufficient, but it cannot be achieved without input-legitimacy.

In addition, the second precondition that the OMC can be based upon output-legitimacy if its results are pareto-optimal, or have no redistributive effects, does not appear to be fulfilled. As stated above, the OMC promotes fundamental social policy concepts which, if influencing national policymaking, affect the majority of the population. These policies will also barely be pareto-optimal. For example, the European Employment Strategy and OMC for social inclusion promote policies reducing 'welfare dependency' by cutting benefits and imposing stricter conditionality upon the receipt of benefits. Whilst such policies may have a positive effect upon overall employment rates, they may have a negative impact upon the well-being of benefit 
claimants and do not appear to contribute to greater social equality or poverty reduction. This argument becomes even more relevant if one considers that the OMC, and the European Employment Strategy in particular, has been linked to the European Social Fund much more closely during recent years. ${ }^{6}$ Therefore, the EES potentially possesses concrete financial and (re)distributive effects. On a more abstract level, authors such as Lord and Beetham (2001, p. 449) have argued that even if policies are pareto-optimal, policy-makers must often choose between different pareto-optimal solutions and consequently consensus upon the basis of this choice may not exist. Furthermore, it is possible for the benefits of a specific pareto-optimal solution to be unevenly distributed (Schäfer, 2006, p. 194).

Two conclusions can be drawn from the debate regarding the OMC's effectiveness. Firstly, from experience of the initial ten years it is evident that the OMC has not been effective in generating output-legitimacy as it has not successfully strengthened the European Union's social dimension. Secondly, this article argues that even if it were effective, the OMC's legitimacy cannot solely rely upon output-legitimacy as this would be inappropriate. In addition, output-legitimacy cannot be achieved without input-legitimacy since it is impossible to identify citizens' interests in isolation of input-legitimate policy-making processes. The OMC therefore also requires input-legitimacy. This dimension will be explored in the following section.

\section{The OMC's Input-Legitimacy}

Recently, various authors have highlighted a need for greater attention to be attributed to the OMC's input-legitimacy (Benz, 2007; Borrás and Conzelmann, 2007; Duina and Raunio, 2007; Hatzopoulos, 2007; Kröger, 2007; Papadopoulos, 2007; Radulova, 2007; Tsakatika, 2007; Wincott, 2006). Within this literature, however, different understandings of input-legitimacy are employed (Borrás and Conzelmann, 2007; De la Porte and Nanz, 2004; Kröger, 2007). I therefore propose contrasting representative-parliamentarian and stakeholder-participation models of input-legitimacy. The representativeparliamentarian model of input-legitimacy is orientated towards Scharpf's original notion of this term. According to this, input-legitimacy is generated if the 'will of the people' is authentically expressed and directed into the policy-making process, primarily through majoritarian parliamentary decisions (Scharpf 1999, pp. 6 and 9). A second understanding of inputlegitimacy, employed in the OMC literature, assumes that political interests are ideally directed into the policy-making process via a broad participatory

${ }^{6}$ See footnote 3 above. 
model including not only citizens but also a variety of 'stakeholders' (Borrás and Conzelmann, 2007, p. 542; De la Porte and Nanz, 2004, p. 272). This type of participation can complement, and sometimes also replace, parliamentary democracy.

First I argue that the EU provides for a stakeholder-participation model of input-legitimacy within the OMC. I will subsequently explain the way in which this model has been theoretically promoted by the concept of directlydeliberative polyarchy (Cohen and Sabel, 1997; Dorf and Sabel, 1998; Eberlein and Kerwer, 2004; Gerstenberg and Sabel, 2002; Sabel and Zeitlin, 2007; Smismans, 2005). In addition, I will examine the participatory practices within the OMC to investigate whether standards set by the EU are achieved. Finally, I will discuss the appropriateness of directly-deliberative polyarchy in legitimizing the $\mathrm{OMC}$.

\section{Stakeholder Participation Within the OMC}

The EU has presented the OMC as a governance tool open for broad direct participation of stakeholders such as interest groups, NGOs, regional and local authorities and experts (see Commission, 2001, pp. 10 and 22; European Council, 1997, para 14). According to the EU Commission and the Council, national governments should consult these stakeholders and local or regional authorities before OMC guidelines or objectives are adopted and, most significantly, in drafting their 'National Reform Programmes' and 'National Strategic Reports'. In contrast to direct stakeholder participation, parliaments at the EU and national levels play only a minor role within OMC processes (Duina and Raunio, 2007; Tsakatika, 2007; Zeitlin, 2005, p. 460). ${ }^{7}$

However, the model of stakeholder participation has clearly been perceived as a positive feature of the $\mathrm{OMC}$ and as 'one dimension of the whole issue of accountability, democratization and legitimacy of the new mode of governance' (Radaelli, 2003, p. 59). Direct stakeholder participation has also been strongly supported by proponents of a new democracy model referred to as directly-deliberative polyarchy (Cohen and Sabel, 1997; Dorf and Sabel, 1998; Gerstenberg and Sabel, 2002; Sabel and Zeitlin, 2007).

Proponents of directly-deliberative polyarchy emphasize the OMC's potential to provide a blueprint for a new model of EU democracy and are therefore optimistic that the OMC could contribute to an enhanced quality of

\footnotetext{
${ }^{7}$ Duina and Rauino (2007) promote a more balanced view of the relationship between the OMC and national parliaments, arguing that the OMC provides an official tool for policy learning within national parliaments. This view can be criticized from two perspectives, however. Firstly, it favours outputlegitimacy over input-legitimacy, and secondly it overlooks the fact that explicit discussion of the OMC in national parliaments, which currently does not take place, would be a pre-condition for transparent and politicized 'policy learning'.
} 
democracy within the EU. Directly-deliberative polyarchy is perceived as an alternative to representative and constitutional democracy (Cohen and Sabel, 1997; Dorf and Sabel, 1998; Gerstenberg and Sabel, 2002, p. 294). It essentially argues that representative and constitutional democracy is no longer a desirable and feasible model due to society's increasing diversity and volatility. Directly-deliberative polyarchy therefore proposes that decisionmaking and implementation should be undertaken by local political units whilst central administration, parliament and courts provide only the framework for such decentralized decision-making and monitoring (Cohen and Sabel, 1997; Dorf and Sabel, 1998; Gerstenberg and Sabel, 2002, p. 294). In return for greater policy-making authority, local units must provide central and higher level units with information regarding their solutions, experiences and performance, which can then be disseminated and publicized to other local units. Local policy-making is directly-deliberative, as a wide range of political actors participate in local-decision-making through deliberation, or the exchange of arguments mutually acknowledged as rational (Cohen and Sabel, 1997, p. 320).

Directly-deliberative polyarchy assumes that policy solutions must be found during the problem-solving process since the creation and implementation of regulations needs to be more flexible and responsive to rapidly changing social contexts (Sabel and Zeitlin, 2007, p. 37). Consequently, rule-makers and rule-takers can no longer be clearly distinguished but mutually depend upon one another. Therefore, a strict separation of powers is not feasible according to directly-deliberative polyarchy; decision-making and implementation are merged within local units in which citizens, interest groups as well as both private and voluntary organizations participate.

Directly-deliberative polyarchy also provides an alternative model of accountability within the OMC. For instance, Sabel and Zeitlin (2007) argue that whilst the OMC does not fulfil traditional criteria of hierarchical principal-agent accountability, it does provide for horizontal 'dynamic accountability' through peer review. The concept of horizontal, dynamic accountability is based upon the notion that in situations where 'actors [...] learn what problem they are solving, and what solution they are seeking, through the very process of problem solving' (Sabel and Zeitlin, 2007, p. 37), accountability is not about compliance by the agent to the principle's rules but lies in the mutual and deliberative control between actors in networks (see also Tsakatika, 2007, p. 555).

From this review of EU standards regarding OMC participation, as well as the model of directly-deliberative polyarchy, one must firstly question whether these standards are fulfilled and how the model of participation within the OMC can be assessed. Secondly, one must discuss whether 
directly-deliberative polyarchy is an appropriate model for legitimizing the OMC.

\section{Assessing Participation and Directly-Deliberative Polyarchy}

In order to assess the appropriateness of the stakeholder-participation model of input-legitimacy in legitimizing the OMC, I will firstly review the available evidence regarding the current practice of participation in OMC processes.

At the European level, 'stakeholder' participation differs between the European Employment Strategy (EES) and the OMC in social inclusion and protection. Article 128 of the Treaty of the European Communities requires the Council to consult the Economic and Social Committee and the Committee of the Regions before the employment guidelines are adopted. More informally, the European social partner organizations, such as the European Trade Union Confederation and the Union des Industries de la Communauté Européenne (UNICE), are also consulted in EES matters and some authors maintain that their right to consultation can be derived from Article 130 of the Treaty (De la Porte and Pochet, 2005, p. 363). For the OMC in social inclusion and protection, no such treaty provisions exist regarding the consultation of stakeholders. However, several European organizations in the area of anti-poverty policy, such as the European Anti-Poverty Network, are informally consulted and issue opinions regarding the OMC. No clear rules exist regarding which European non-governmental organizations (NGOs) should be consulted and the risk that some may be sidelined in this process prevails (De la Porte and Pochet, 2005, p. 376). In addition, the Employment and Social Protection Committees, which play an important role in formulating OMC objectives and developing quantitative indicators, regularly invite experts and other actors for consultation (De la Porte and Pochet, 2005, p. 375). However, the actors that are consulted as well as the exact role that they play remain opaque (Berghman and Okma, 2002).

At the national level, an increasing amount of empirical data regarding the participation of stakeholders within the OMC exists, although it remains incomplete. A number of general conclusions have been drawn within publications by authors such as de la Porte and Pochet (2005), Zeitlin (2005) and Friedrich (2006). They concur that overall, stakeholder participation within the $\mathrm{OMC}$ has increased. Within the $\mathrm{OMC}$ for social inclusion and protection, NGOs possess a more significant role than social partners, whilst the opposite is true for the European Employment Strategy (De la Porte and Pochet, 2005). This is predominantly explained by the fact that as employment policy is dominated by the social partners, both governments and they themselves oppose closer participation by NGOs in that area. In addition, the OMC for 
social inclusion and protection only partially overlaps with social partners' remits, resulting in insufficient incentives to participate in these branches of the OMC. Authors such as de la Porte and Pochet (2005, p. 382) and Casey (2005) have noted that the overall level of participation by social partners remains less significant than expected. One explanation for this phenomenon is that social partners are intrinsically ambivalent regarding the European Employment Strategy, since it does not fully support their political interests (De la Porte and Pochet, 2005, p. 369). In contrast, NGOs are generally less established policy actors at the national level. The OMC therefore provides a potential channel through which to express their views (De la Porte and Pochet, 2005, p. 383). In some countries, new consultation forums have been developed with regards to the $\mathrm{OMC}$, strengthening communication between the government and NGOs and/or social partners (Zeitlin, 2005, p. 462). In a number of countries, regional and local authorities are also increasingly consulted regarding OMC processes. Zeitlin (2005, p. 469), for instance, assumes that they have pressed for the possibility of participation in countries where their autonomy is more contested, whilst they have been more sceptical regarding the $\mathrm{OMC}$ in countries in which they possess entrenched authorities.

Overall, stakeholder participation in national OMC processes has not fully fulfilled initial expectations and remains uneven between countries. The latter applies both to the level of participation as well as the ways in which stakeholders are allowed to influence OMC processes. ${ }^{8}$ The level and type of actor participation has also changed considerably over time in certain countries, leading to an inability to identify regular patterns (Kröger, 2007). Several authors also report incidences of governments rejecting requests by certain stakeholders to participate (De la Porte and Pochet, 2005; Jacobsson, 2005, p. 117; Kröger, 2007).

A significant criticism of the current model of OMC participation refers to the marginalization of parliaments at the EU and national levels in the process. According to Article 128 of the Treaty of the European Communities, the European Parliament must be consulted regarding the guidelines of the European Employment Strategy, whilst no such rules exist in relation to other social policy strands of the OMC. However, a study by Tsakatika (2007, p. 553) concludes that the involvement of the European Parliament in OMC processes has increased over the years, particularly since the mid-term review of the Lisbon Strategy in 2005 in which the Commission called for more active input by the European Parliament to the Commission's annual strategic report (Tsakatika, 2007, p. 552). In November 2004, a group comprised of 33

\footnotetext{
${ }^{8}$ For example, in some countries social partners and/or regional authorities draft sections of the National Reform Programmes, in others they are merely consulted. 
members of the European Parliament covering all standing groups was established to review issues related to the Lisbon Strategy (Tsakatika, 2007, p. 553). This group drafts an annual resolution on the Lisbon Agenda which is debated and adopted by the plenary and within joint parliamentary meetings between members from the European and national parliaments before being sent to the Spring Council (Tsakatika, 2007, p. 553). Although this development represents a stronger role for the European Parliament in the Lisbon Strategy, more empirical analysis is required in order to examine whether the social policy OMCs are as significant within the European Parliament's discussion and resolution as the internal market aspects of the Lisbon Strategy and how Member State representatives respond to the resolution's social policy aspects at the Spring Summits.

Many authors also conclude from the empirical evidence that national parliaments remain marginalized within national OMC processes since only few countries involve them in the creation of National Reform Programmes (De la Porte and Pochet, 2005; Duina and Raunio, 2007; Friedrich, 2006; Kröger, 2007; Tsakatika, 2007). Tsakatika (2007, p. 552) concludes from a comparative analysis of Member States' parliamentary involvement within OMC processes that in 2006, the Lisbon Strategy was debated in national parliaments' plenaries or committees in only two Member States, the United Kingdom and Belgium. In all other Member States, parliamentary input into the Lisbon process was rated at a very low level and in nine of all 25 Member States, national parliaments were not even involved at committee level (Tsakatika, 2007, p. 553).

This evidence demonstrates that participation within OMC processes is based upon an input-legitimacy model of stakeholder participation rather than a representative-parliamentarian model. From the perspective of representative-parliamentarian input-legitimacy, a number of problems exist with the current model of OMC participation. Firstly, no clear criteria are established at the EU level regarding which actors should participate in the development of OMC objectives or national reform programmes. Guidelines regarding the rights and responsibilities of stakeholders participating in $\mathrm{OMC}$ processes are also absent from this process.

One can therefore argue that current arrangements for stakeholder participation within the OMC are detrimental to the OMC's transparency and accountability. In general, Member State citizens are not well informed regarding OMC processes or the roles played by different institutions and actors at the EU and national levels within the OMC. The majority of EU citizens are furthermore unaware that the OMC and Lisbon strategy even exist (European Commission, 2006, p. 14). A significant illustration of the OMC's opaqueness at the EU level is evident within participation in the Employment 
and Social Protection Committees. Both are crucial in developing quantitative indicators as well as discussing proposals for guidelines and objectives. The Committees may consult experts, interest groups and voluntary organizations. However, no clear rules exist to govern these consultations and meeting minutes are not publicly available. Therefore, stakeholder and experts' influence upon OMC indicators and objectives remains unclear.

The OMC is not only opaque in terms of stakeholder participation but also at a more general level concerning the role of national governments in OMC negotiations. As the minutes of Council discussions are not publicly available, no transparency exists with regards to the positions taken by government representatives. National citizens are therefore unable to reveal the role that their, and other Member State, governments have played in OMC decisions. This weakens the accountability of national governments to their parliaments and electorates. This accountability is further weakened by the fact that there is very little media and parliamentary debate regarding the OMC. Potentially, executives are able to employ the OMC in order to pressure for unpopular policy change at the national level, ${ }^{9}$ whilst the role played by governments in EU level OMC negotiations remains opaque to national electorates (Büchs, 2008).

Furthermore, it remains questionable exactly how input-legitimacy orientated the stakeholder participation model is, as one of its aims appears to be the development of more effective policies. For example, the logic behind this model becomes evident within the Commission's White Paper on Governance, according to which stakeholder participation shall enhance the prospects for 'effective' policies (Commission, 2001, p. 10). The underlying logic implies that policies will be more effectively implemented if stakeholder interests are acknowledged in the early stages of the policy-making process.

Generally, direct participation of stakeholders and local or regional authorities within policy-making does not increase representativeparliamentarian input-legitimacy as these actors do not represent the 'will' of the electorate but specific, partially 'private' interests. Furthermore, direct stakeholder participation is likely to privilege actors able to organize themselves and express a shared interest, as well as those important to policy implementation. This may, however, occur at the expense of third parties who are affected by the policies but are not directly responsible for their implementation. Direct participation of selected civil society actors can,

\footnotetext{
${ }^{9}$ Whilst this might not be the default mode of OMC usage at the domestic level, there is evidence that some governments use the OMC in this way, for instance in Germany (Büchs, 2008), the Netherlands (Visser, 2005, p. 199) and France (Erhel et al., 2005, p. 217). 
therefore, even impede the enhancement of representative-parliamentarian input-legitimacy.

However, some authors have argued that a representative-parliamentarian model of democracy is no longer feasible, promoting the notion that the OMC could instead be legitimized by the alternative model of directly-deliberative polyarchy. Some proponents of directly-deliberative polyarchy have stated that the OMC has thus far been unable to achieve this ideal (Smismans, 2005). Nonetheless, assuming that this model has the potential to be realized, one must discuss whether it would be an appropriate model for legitimizing the OMC.

The model of directly-deliberative polyarchy certainly addresses some important concerns regarding the viability of representative-parliamentarian democracy. However, a number of weaknesses are inherent within this model, leading one to conclude that it is inadequate to legitimize the OMC. ${ }^{10}$ Firstly, directly-deliberative polyarchy appears to underestimate power-asymmetries between citizens and various societal groups regarding participation in local policy-making. The model suggests that citizens, interest groups, private and voluntary organizations and NGOs possess equal influence upon local policy-making. The underlying assumption of this model perceives different actors as dependent upon one another in such a way that all participants are essentially equal, resulting in policies that equally serve the interests and needs of all participants (Gerstenberg and Sabel, 2002, p. 293). However, this is an idealistic belief, since it is highly likely that local actors are diversely dependent upon one another, possessing differing capabilities and abilities to organize themselves and influence policies, and that power asymmetries between local actors therefore inevitably exist. This is particularly the case in the area of social policy, which has potentially redistributive consequences.

Furthermore, it is highly questionable whether the traditional model of the separation of powers should be replaced by a model of horizontal or 'dynamic accountability' (Sabel and Zeitlin, 2007). Even if it can probably never be fully realized, the principle of the separation of powers in parliamentary democracies is crucial. It serves the inhibition of authoritarianism and monopolization of power by preventing rule-makers from creating selfserving rules unresponsive to requirements of the 'common good' or will of citizens. 'Hierarchical' accountability of governments to parliaments and parliaments to the general electorate based upon the principle of separation of powers still appears to be the most convincing and effective method of preventing the misuse of political power by powerful groups in society.

${ }^{10}$ See also Scheuermann (2004) for a critical debate of directly-deliberative polyarchy. 
Finally, directly-deliberative polyarchy promotes the localization of policymaking and implementation, maintaining that it is the most effective way of generating locally tailored solutions through the direct involvement of local actors affected by the adopted policies. However, certain problems require national or supranational policies in order to avoid negative effects of policies in one local unit upon another or a 'race-to-the-bottom'. Social and environmental standards provide good examples of this issue. In addition, localization of social policies potentially contrasts with equal rights deriving from social citizenship if it produces a diversification of available policies and access to services. Regional inequalities are particularly likely to increase if local units endure the full financial responsibilities of their policies and if the national or supranational level does not provide for redistribution between poorer and richer regions.

Overall, it therefore appears that the model of directly-deliberative polyarchy does not provide a convincing model for conceptualizing the OMC's input-legitimacy.

\section{Conclusion}

This article argued that the OMC's legitimacy and democratic quality are deficient in terms of both output- and input-legitimacy. Upon initial assessment, the OMC does not appear to possess the ability to generate outputlegitimacy since it is not sufficiently effective. In particular, its broader goals of strengthening the EU's social dimension, combating poverty and social exclusion and balancing 'negative' and 'positive' integration have not been achieved. However, even if the OMC were more effective, a number of criticisms regarding claims that it could be legitimized solely on the basis of its outputs would remain. These concerns primarily surround the fact that its objectives are not consensual and may have (re)distributive effects. Controversial policies with (re)distributive effects must also have their basis in input-legitimacy; output-legitimacy alone remains insufficient. In addition, input-legitimacy is required in order to achieve output-legitimacy, as citizens' interests cannot be defined in isolation of input-legitimate policy-making processes.

It is therefore necessary to also analyse the OMC's input-legitimacy. This examination demonstrated that a model of direct stakeholder participation is currently in use as opposed to provisions for representative-parliamentarian input-legitimacy. Several problems were identified with this approach. Stakeholder participation remains inconsistent and creates problems in terms of both transparency and accountability. 
An underlying difficulty is also evident in the absence of clear rules regarding the level and type of stakeholder participation. One may also conclude that the model of directly-deliberative polyarchy fails to provide a convincing alternative that could legitimize the stakeholder-participation model of input-legitimacy within the OMC.

This article therefore argues that the current stakeholder model of participation not only marginalizes parliaments at the EU and national levels but is also detrimental to national parliamentary democracy more generally as it strengthens executives whilst weakening parliamentary power in national policy-making processes. It is thus crucial to strengthen representativeparliamentarian input-legitimacy both within the OMC and at the national level. It is consequently imperative to examine whether, and if so, how, this could be achieved.

One radical proposal is the abolishment of the OMC, as it is not sufficiently effective in strengthening a social Europe whilst it informally influences national policy-making and therefore raises legitimacy concerns. One alternative would be to leave responsibility for social policy with the Member States and 're-parliamentarize' them. However, this is not a preferable option since social policies must be co-ordinated at the EU level to strengthen the social dimension of the common market.

Another radical reform option that has been discussed, originally by Scharpf (2002), is to adopt a set of general but legally binding OMC objectives through the co-decision procedure of the Council and European Parliament. Member State governments would be obliged to implement these 'framework directives' whilst retaining reasonable discretion regarding the concrete measures adopted. Whilst this proposal promises to be the most effective and legitimate option if it were workable, it is currently the least probable scenario since it is highly unlikely that the 27 Member State governments would be able to agree consensually upon any binding framework directives.

A range of further proposals can alternatively be made to improve the OMC's transparency, accountability and input-legitimacy. For instance, even if $\mathrm{OMC}$ objectives are adopted as non-binding guidelines, the European Parliament could have the right of co-decision in the decision-making process. In the joint parliamentary sessions between the European and national parliaments, coverage of the social policy OMCs should be ensured so that both levels have an input upon OMC objectives. These measures would enhance the OMC's publicity and enable open political discussion of its objectives.

Much more detailed information should be made available of Council discussions preceding the adoption of OMC objectives, ideally in form of 
discussion transcripts similar to those of second chamber parliamentary discussions at the national level, in order to strengthen the transparency and accountability of national ministers to their parliaments and electorates. This should also apply to discussions of the Social Protection and Employment Committees, as they undertake crucial decisions concerning quantitative indicators and targets within the OMC.

Moreover, whilst the current situation provides no political consensus for rendering $\mathrm{OMC}$ objectives legally binding, much clearer and potentially legally binding rules should exist regarding the decision-making procedures of OMC objectives at the EU, as well as national levels. For example, national governments could be required to consult with national parliaments before the objectives and guidelines are adopted at the EU level. National governments could also be required to establish clear rules, according to national traditions, regarding the consultation with actors such as social partners, NGOs, sub-national authorities and citizen forums. Furthermore, they should be obliged to provide detailed and publicly accessible information concerning the level and scope of stakeholder involvement. This may include information regarding whether stakeholders were consulted or allowed to contribute to the national reports or programmes and the ways in which governments are obliged to respond to their proposals.

Another possibility for raising awareness of the OMC and making the association between EU and national social policy-making more transparent may be obliging national parliaments to discuss whether, and if so, how, these objectives could be linked to national policy-making. This would provide a basis for a public and transparent discussion regarding the connection between EU social policies and national policy-making. The obligation for this discussion does not imply that national parliaments must adopt the objectives, as they could still be rejected once justifications are provided. This process would limit the current dominance of executives in the OMC process and also strengthen the legislative branch of policy-making.

These proposed reform options remain inconclusive and are primarily intended to instigate discussion. Solutions must be found that strengthen the required representative-parliamentarian channel of OMC input-legitimacy and prevent it being replaced by a stakeholder-participation model. This would also serve to strengthen parliamentary democracy at the national level.

\section{Correspondence:}

Milena Büchs

University of Southampton

M.Buechs@soton.ac.uk 
JOBNAME: No Job Name PAGE: 19 SESS: 25 OUTPUT: Tue Jun 10 18:16:48 2008 SUM: D472A5F4

/v2451/blackwell/journals/JCMS_v46_i4/02jcms_804

HOW LEGITIMATE IS THE OPEN METHOD OF CO-ORDINATION?

\section{References}

Amitsis, G., Berghman, J., Hemerijck, A., Sakellaropoulos, T. and Stergiou, A. (2003) 'Connecting Welfare Diversity within the European Social Model'. Background Report to the International Conference of the Greek Presidency of the European Union, 21 to 22 May 2003, Ioannina.

Ashiagbor, D. (2005) The European Employment Strategy. Labour Market Integration and New Governance (Oxford: Oxford University Press).

Benz, A. (2007) 'Accountable Multi-Level Governance by the Open Method of Co-ordination?' European Law Journal, Vol. 13, No. 4, pp. 505-22.

Berghman, J. and Okma, K. (2002) 'The Method of Open Co-ordination: Open Procedures or Closed Circuit? Social Policy-Making between Science and Politics'. European Journal of Social Security, Vol. 4, No. 4, pp. 331-56.

Borrás, S. and Conzelmann, T. (2007) 'Democracy, Legitimacy and Soft Modes of Governance in the EU: the Empirical Turn'. Journal of European Integration, Vol. 29, No. 5, pp. 531-48.

Büchs, M. (2007) New Governance in European Social Policy: the Open Method of Co-ordination (Basingstoke: Palgrave Macmillan).

Büchs, M. (2008) 'The Open Method of Co-ordination as a "Two-Level Game"'. Policy and Politics, Vol. 36, No. 1, pp. 21-37.

Casey, B. (2005) 'Building Social Partnership? Strengths and Shortcomings of the European Employment Strategy’. Transfer, No. 1, pp. 45-63.

Cohen, J. and Sabel, C. (1997) 'Directly-Deliberative Polyarchy'. European Law Journal, Vol. 3, No. 4, pp. 313-42.

Commission of the European Communities (2001) 'European Governance. A White Paper'. Luxembourg: COM (2001) 428 final, 25.07.2001, Brussels.

Commission of the European Communities (2005) 'Working Together for Growth and Jobs. A New Start for the Lisbon Strategy. Communication to the Spring Council, from President Barroso in Agreement with Vice-President Verheugen'. COM (2005) 24, 02.02.2005, Brussels.

Commission of the European Communities (2006) 'European Employment and Social Policy, Special Eurobarometer 261'. available at: «http://ec.europa.eu/ public_opinion/archives/ebs/ebs261_en.pdf», accessed on 29 May 2007.

De la Porte, C. and Nanz, P. (2004) 'OMC - A Deliberative-Democratic Mode of Governance? The Cases of Employment and Pensions'. Journal of European Public Policy, Vol. 11, No. 2, pp. 267-88.

De la Porte, C. and Pochet, P. (2002a) 'Introduction'. In De la Porte, C. and Pochet, P. (eds.) Building Social Europe through the Open Method of Co-ordination (Brussels: P.I.E.-Peter Lang).

De la Porte, C. and Pochet, P. (2002b) 'Supple Co-ordination at EU Level and the Key Actors' Involvement'. In De la Porte, C. and Pochet, P. (eds) Building Social Europe through the Open Method of Co-ordination (Brussels: P.I.E-Peter Lang).

De la Porte, C. and Pochet, P. (2005) 'Participation in the Open Method of Co-ordination: The Cases of Employment and Social Inclusion'. In Zeitlin, J., 
Pochet, P. and Magnusson, L. (eds) The Open Method of Co-ordination in Action: The European Employment and Social Inclusion Strategies (Brussels: Peter Lang).

Dorf, M.C. and Sabel, C.F. (1998) 'A Constitution of Democratic Experimentalism'. Columbia Law Review, Vol. 98, No. 2, pp. 267-473.

Duina, F. and Raunio, T. (2007) 'The Open Method of Co-ordination and National Parliaments: Further Marginalization or New Opportunities?' Journal of European Public Policy, Vol. 14, No. 4, pp. 489-506.

Eberlein, B. and Kerwer, D. (2004) 'New Governance in the European Union: A Theoretical Perspective'. JCMS, Vol. 42, No. 1, pp. 121-42.

Erhel, C., Mandin, L. and Palier, B. (2005) 'The Leverage Effect: the Open Method of Co-ordination in France'. In Zeitlin, J., Pochet, P. and Magnusson, L. (eds) The Open Method of Co-ordination in Action: The European Employment and Social Inclusion Strategies (Brussels: Peter Lang).

Eriksen, E.O. and Fossum, J.E. (2000) Democracy in the European Union. Integration through Deliberation? (London / New York: Routledge).

European Council (1997) 'Presidency Conclusions'. Amsterdam European Council, 16 and 17 June 1997.

European Council (2000) 'Presidency Conclusions'. Nice European Council, 7, 8 and 9 December 2000.

European Parliament/Council (2006) 'Regulation (EC) No 1091/2006 of the European Parliament and of the Council of 5 July 2006 on the European Social Fund and repealing Regulation No 1784/1999'. Official Journal of the European Union, L210, 31.7.2006, pp. 12-18.

Ferrera, M. and Rhodes, M. (2000) 'Building a Sustainable Welfare State'. West European Politics, Vol. 23, No. 2, Special Issue, pp. 257-82.

Follesdal, A. and Hix, S. (2005) 'Why There is a Democratic Deficit in the EU: A Response to Majone and Moravcsik'. European Governance Papers No. C-05/02, available at: «http://www.connex/network.org/eurogov/».

Friedrich, D. (2006) 'Policy Process, Governance and Democracy in the EU: the Case of the Open Method of Co-ordination on Social Inclusion in Germany'. Policy \& Politics, Vol. 34, No. 2, pp. 367-83.

Gerstenberg, O. and Sabel, C.F. (2002) 'Directly-Deliberative Polyarchy: an Institutional Ideal for Europe?' In Joerges, C. and Dehousse, R. (eds) Good Governance in Europe's Integrated Market (Oxford / New York: Oxford University Press).

Habermas, J. (2001 [1998]) 'The Post-National Constellation and the Future of Democracy'. In Habermas, J. (ed) The Postnational Constellation. Political Essays (Cambridge: Polity).

Hatzopoulos, V. (2007) 'Why the Open Method of Co-ordination is Bad for You: a Letter to the EU'. European Law Journal, Vol. 13, No. 3, pp. 309-42.

Jacobsson, K. (2005) 'Trying to Reform the "Best Pupils in the Class"? The Open Method of Co-ordination in Sweden and Denmark'. In Zeitlin, J., Pochet, P. and Magnusson, L. (eds.) The Open Method of Co-ordination in Action: The European Employment and Social Inclusion Strategies (Brussels: Peter Lang). 
Jacobsson, K. and Vifell, A. (2002) 'Integration by Deliberation? Dynamics of Soft Regulation in the Case of EU Employment Policy'. Paper for presentation at the ECPR 1st Pan-European Conference on European Union Politics, Bordeaux 26-28 September 2002.

Kenner, J. (2005) 'The Constitution that Never Was: Is There Anything Worth Salvaging from the Wreckage?' Industrial Relations Journal, Vol. 36, No. 6, pp. 541-67.

Kröger, S. (2007) 'The End of Democracy as We Know It? The Legitimacy Deficits of Bureaucratic Social Policy Governance'. Journal of European Integration, Vol. 29 , No. 5, pp. 565-82.

López-Santana, M. (2006) 'The Domestic Implications of European Soft Law: Framing and Transmitting Change in Employment Policy'. Journal of European Public Policy, Vol. 13, No. 4, pp. 481-99.

Lord, C. and Beetham, D. (2001) 'Legitimizing the EU: Is there a "PostParliamentary Basis" for its Legitimation?' JCMS, Vol. 39, No. 3, pp. 44362.

Majone, G. (1998) 'Europe's "Democracy deficit": The Question of Standards'. European Law Journal, Vol. 4, No. 1, pp. 5-28.

Moravcsik, A. (2002) 'In Defence of the "Democratic Deficit": Reassessing Legitimacy in the European Union'. JCMS, Vol. 40, No. 4, pp. 603-24.

Papadopoulos, Y. (2007) 'Problems of Democratic Accountability in Network and Multilevel Governance'. European Law Journal, Vol. 13, No. 4, pp. 46986.

Radaelli, C.M. (2003) 'The Open Method of Co-ordination: A New Governance Architecture for the European Union?' Swedish Institute for European Policy Studies, available at: «http://www.sieps.se/publ/rapporter/bilagor/20031.pdf».

Radulova, E. (2007) 'The OMC: An Opaque Method of Consideration of Deliberative Governance in Action?' Journal of European Integration, Vol. 29, No. 3, pp. 363-80.

Sabel, C.F. and Zeitlin, J. (2007) 'Learning from Difference: The New Architecture of Experimentalist Governance in the European Union'. European Governance Paper No. C-07-02 (EUROGOV), May 10 2007, available at «http://www. connex-network.org/eurogov/pdf/egp-connex-C-07-02.pdf».

Schäfer, A. (2006) 'Die demokratische Grenze output-orientierter Legitimation'. Integration, No. 3, pp. 187-200.

Scharpf, F.W. (1999) Governing in Europe: Effective and Democratic? (Oxford: Oxford University Press).

Scharpf, F.W. (2002) 'The European Social Model: Coping with the Challenges of Diversity'. JCMS, Vol. 40, No. 4, pp. 645-70.

Scheuermann, W.E. (2004) 'Democratic Experimentalism or Capitalist Synchronization? Critical Reflections on Directly-Deliberative Polyarchy'. Canadian Journal of Law and Jurisprudence, Vol. 17, pp. 101-27.

Smismans, S. (2005) 'Reflexive Law in Support of Directly Deliberative Polyarchy: Reflexive-Deliberative Polyarchy as a Normative Frame for the OMC'. In 
Schutter, O.D. and Deakin, S. (eds) Social Rights and Market Forces: is the Open Co-ordination of Employment and Social Policies the Future of Social Europe? (Brussels: Bruylant).

Telò, M. (2003) 'Governance and Government in the European Union: The Open Method of Co-ordination'. In Rodrigues, M.J. (ed) The New Knowledge Economy in Europe. A Strategy for International Competitiveness and Social Cohesion (Cheltenham: Edward Elgar).

Trubek, D. and Trubek, L. (2005) 'The Open Method of Co-ordination and the Debate Over "Hard" and "Soft" law'. In Zeitlin, J., Pochet, P. and Magnusson, L. (eds) The Open Method of Co-ordination in Action: The European Employment and Social Inclusion Strategies (Brussels: Peter Lang).

Tsakatika, M. (2007) 'A Parliamentary Dimension for EU Soft Governance'. Journal of European Integration, Vol. 29, No. 5, pp. 549-64.

Visser, J. (2005) 'The Open Method of Co-ordination as Selective Amplifier for National Strategies of Reform. What the Netherlands Want to Learn from Europe'. In Zeitlin, J., Pochet, P. and Magnusson, L. (eds) The Open Method of Co-ordination in Action: The European Employment and Social Inclusion Strategies (Brussels: Peter Lang).

Wincott, D. (2006) 'European Political Development, Regulatory Governance and the European Social Model: the Challenge of Substantive Legitimacy'. European Law Journal, Vol. 12, No. 6, pp. 743-63.

Zeitlin, J. (2005) 'The Open Method of Co-ordination in Action: Theoretical Promise, Empirical Realities, Reform Strategy'. In Zeitlin, J., Pochet, P. and Magnusson, L. (eds) The Open Method of Co-ordination in Action: The European Employment and Social Inclusion Strategies (Brussels: Peter Lang).

Zeitlin, J., Pochet, P. and Magnusson, L. (2005) The Open Method of Co-ordination in Action: The European Employment and Social Inclusion Strategies (Brussels: Peter Lang). 
JOBNAME: No Job Name PAGE: 23 SESS: 25 OUTPUT: Tue Jun 10 18:16:48 2008 SUM: 0414A6C1 /v2451/blackwell/journals/JCMS_v46_i4/02jcms_804

\begin{tabular}{|l|l|}
\hline \multicolumn{2}{|c|}{ SNP Best-set Typesetter Ltd. } \\
\hline Journal Code: JCMS & Proofreader: Elsie \\
\hline Article No: 804 & Delivery date: 10 June 2008 \\
\hline Page Extent: 22 & \\
\hline
\end{tabular}

